\title{
Supporters' responses to contested trade negotiations: the European Commission's rhetoric on the Transatlantic Trade and Investment Partnership
}

\author{
Patricia Garcia-Duran Huet \\ University of Barcelona \\ Leif Johan Eliasson \\ East Stroudsburg University
}

\begin{abstract}
Negotiations on the Transatlantic Trade and Investment Partnership (TTIP) commenced in 2013, and soon became the most controversial bilateral trade agreement ever attempted by the European Union (EU). When trying to understand the escalating debate over the proposed agreement, most analyses have highlighted opposition to the deal, especially from civil society organisations. However, a full understanding of the debate surrounding the TTIP requires analysis of supporters' responses, as these changed in response to strategies used by opponents of the agreement. This article uses a novel approach in trade policy scholarship-rhetorical analysis - to focus on the European Commission Trade Directorate's response to contestation over TTIP. Drawing on Albert Hirschman's (1991) work on the 'rhetoric of reaction', this article identifies the rhetorical strategies used by EU trade commissioners from 2013 to 2016. It outlines the evolution of the rhetoric and accompanying changes in process and policy, providing insights on the impact of TTIP politicisation on the guiding principles of the EU's trade policy.
\end{abstract}

\section{Introduction}

The Transatlantic Trade and Investment Partnership (TTIP) has become the most controversial bilateral trade agreement ever attempted by the European Union (EU). Negotiations began in 2013, and supporters, including public officials and private interest groups, emphasised from the beginning the agreement's economic and geostrategic benefits (Dempsey 2015; Hamilton 2014). Their argument relied primarily on two premises: that lower tariffs and the removal of non-tariff measures bring economic gains, and that standards agreed upon by the two largest markets (the EU and US) will quickly become global. Civil society organisations (CSOs) such as Public Citizen, the European Consumer Organisation (BEUC), Friends of the Earth, and the Transatlantic Consumer Dialogue (TACD) led the opposition to the agreement. They mobilized resources and galvanised public opinion to an unprecedented extent, adding to traditional opposition to trade deals coming from groups such as labour unions. CSOs argued that the mutual recognition of standards would undermine safety regulations and increase the power of multinationals through the Investment-State Dispute Settlement (ISDS; a system whereby investors can seek redress for compensation against host government violations of the terms of the investment treaty), which opponents said would allow corporations to sue governments, causing 'regulatory chill' (De Ville and Siles-Brügges 2016).

\footnotetext{
${ }^{1}$ Though choosing to focus on the same key issues, and undertaking largely similar actions to further their cause, reformists, such as consumer organizations and trade unions, would accept an agreement with significant alterations on key issues, while rejectionists, such as StopTTIP! and War on Want, oppose an agreement of any kind. In this article we do not differentiate between these two opposition groups for two reasons. First, because the overlap between the groups means the distinction did not substantially affect the debate. Second, because the Commission's rhetoric was largely aimed at a third party, the public.
} 
Both opponents and supporters tried to convince the public of their arguments. Existing analyses of opponents' inroads and supporters' failure to control public debate on the TTIP have highlighted the unprecedented engagement by CSOs. Bauer (2016) has argued that CSOs' influence was facilitated by the use of social media, while others (De Ville and Siles-Brügge 2016; Young 2016; Lamy 2015) have pointed to the equally unprecedented focus their campaign placed on non-tariff barriers. Gheyle (2016) has argued that CSO activism politicised the TTIP, leading to what De Wilde $(2011,566)$ refers to as an increase in the polarisation of opinions, interests and values and the extent to which they are publicly advanced towards the process of policy formulation within the EU.'

Using the public TTIP debate as a case study, this article instead focuses on the rhetorical strategies of T'TIP proponents, asking if supporters' rhetoric changed as the negotiations progressed and opposition intensified and, if so, what the results were of these changes. It specifically focuses on the evolving response of the European Commission's Directorate for Trade, for two reasons. First, because the European Commission has important competences in trade policy, changes in this Directorate's rhetoric can potentially have a direct political impact. Second, the Commission was largely responsible for making the public case in favour of the TTIP agreement. While national governments, business organisations, and a substantial majority of the European Parliament supported the TTIP when launched in 2013, some governments and European Parliamentarians got cold feet as the opposition campaign intensified in 2014 and 2015 (see Siles-Brügge, 2018). Pundits, think tanks, Members of the European Parliament (MEPs), and (unofficially) some Commission staff criticized governments for not explaining and defending TTIP (Aline 2015). ${ }^{2}$ A small number of pro-TTIP organisations (for example TABC, AmCham, BusinessEurope) ran sustained campaigns online (and to a lesser extent on the ground) in 2014 and 2015, but were overshadowed by anti-TTIP social media and public initiatives (Ciofu and Stefanuta 2016; Bauer 2016). ${ }^{3}$ The Transatlantic Business Council (TABC), the most active supportive group on twitter, discontinued its advocacy in 2016, in part because 'no one but the Commission is pushing for it and we are beat online. ${ }^{4}$

In the following analysis, we draw on Albert Hirschman's (1991) seminal work on the 'rhetoric of reaction,' as well as subsequent reviews and revisions. We propose a rhetorical analysis of the Commission's response to TTIP contestation, since the nature of the debate was rhetorical rather than dialectic. Rhetoric is a counterpart to dialectic, as political actors are not 'trying to present arguments that might convince an opponent' but present 'arguments to convince a third party-the audience' (Finlayson 2013, 317). In the TTIP case, both opponents and supporters fought to bring public opinion to their side. The previous pattern of trade policy as an insider's game was no longer applicable, compelling the Commission to actively defend trade negotiations and trade policy in the greater public realm. We chose Hirschman's framework over other rhetorical analysis frameworks (e.g. Schimmelfennig, 2001) because of its focus on reaction; it deals not only with strategies that can be used to challenge a reform or policy change by opponents, but also with responsive strategies supporters can rely on in challenging opponents. It is a framework intended to capture the evolution (and all sides) of debate.

\footnotetext{
${ }^{2}$ Interviews with Commission advisers and business representatives in Brussels and Berlin, April and May 2016, indicated that the Commission was surprised and disappointed by the lack of support it received from Member States.

3 Tweets that include hashtag words generally favourable to the agreement only made up roughly $1 \%$ of total tweets, whereas tweets advocating a clear no (through hashtags like \#stopttip, \#nottip, \#noalttip and others) represented 99\% of total TTIP related activity (Coifu and Stefano 2016). YouTube was similarly dominated by opponents (Eliasson and Garcia-Duran forthcoming).

${ }_{4}^{4}$ TABC representative, Brussels, March 2017.
} 
This article neither assesses the quality or content of arguments made (Garcia-Duran and Eliasson 2017), nor does it analyse the strengths and limits of rhetorical political analysis (Finlayson 2007), the role of the Commission in trade negotiations (Poletti and DeBièvre 2013), or the degree and causes of TTIP politicisation (Gheyle 2016). Its sole focus lies on the European Commission's response to mounting TTIP opposition between summer 2013 and November 2016, when both sides 'froze' negotiations (Borderlex 2016). We focus on rhetoric and its effects. Grube $(2016,534)$ states that 'rhetoric is at one and the same time constitutive and formative of the ideas that are expressed through these words'. Political actors therefore lock in a certain path and struggle to change their rhetoric without losing legitimacy ('rhetorical path dependency'). Schimmelfenning (2001) likewise argues that 'rhetorical commitment' can lead to 'rhetorical entrapment'. We show that TTIP contestation led to changes in the Commission's rhetoric on EU trade policy. It became more conciliatory and functional on certain issues (e.g. transparency), and policy areas (e.g. investorstate dispute settlement), and more intransigent on others (e.g. trade's economic benefits), with changes occurring to both process (e.g. transparency) and policy (e.g. investor dispute settlement).

The next section discusses theory and methodology. The third and fourth sections look to the rhetoric used by the Commission from December 2012 to July 2016. The article concludes with a fifth section analysing our findings.

\section{Analysing rhetorical strategy}

According to Hirschman (1991) there are three principal reactionary theses to a proposed change or reform, each leading to different public debates. ${ }^{5}$ The 'perversity thesis' holds that the proposed change would only 'serve to exacerbate the condition one wishes to remedy...' (p.7) due to imperfect foresight. For example, opponents could estimate and reference China's future economic power in arguing that TTIP will bring economic and geopolitical costs, rather than the benefits claimed by supporters. The 'futility thesis' holds that attempts at social transformation would fail because basic societal structures are unchangeable. In the case of TTIP, opponents could argue that TTIP is unnecessary because trade and investment flows between the US and the EU are already well developed and that they prefer continuing the status quo. Finally, the 'jeopardy thesis' argues that 'the cost of the proposed change or reform is too high because it endangers some previous, precious accomplishment' (p. 7); while the proposed modification may be desirable in itself, it involves unacceptable costs (p. 81). While the first two theses are based on challenging the benefits proclaimed by the supporters, the third admits the possibility of a different perspective: one based on the costs of losing (the benefits of) the status quo and 'the dangers of action' (p.152). The message is simple: 'We lose and we gain, but what we lose is more precious than what we gain.' (p. 123).

In the T'TIP debate, opponents have argued that the agreement would unravel high EU standards and governments' abilities to legislate and regulate health, safety, and welfare provisions in the public interest. To convince the public that TTIP would harm product safety and limit the

\footnotetext{
5 Although the three theses are contradictory Hirschman's theory expressly accommodates the likelihood that their arguments can be used in the course of the same debate, sometimes even by the same person or group. Shorten (2015) has argued that Hirschman's conception of rhetoric has two limitations: first, the subject matter of rhetoric is conceived as an ex post facto rationalisation, and second, it focuses on logos. In other words, Hirschman's taxonomy assumes that supporters and opponents each have a strategy (an interest prior to the articulation of the discourse) and then try to imprint their arguments with (quasi-) logic.
} 
influence of public policies, opponents deliberately and strategically emphasised controversial issues related to food (e.g. hormone treated beef) and Investor-to-State Dispute Settlement systems (ISDS), 'scaring' citizens through associations and hypotheticals (Bauer 2016; Eliasson and GarciaDuran, 2018). Overall, TTIP was framed by opponents as a trade-off between neo-liberalism (or 'wild-west capitalism') and 'popular sovereignty' (for example Friends of the Earth Europe 2015). ${ }^{6}$ In so doing, opponents developed a 'jeopardy thesis' in which the TTIP would erode hard won exigent regulatory standards and public policies in Europe. Thus, supporters encountered rhetoric focused on the "costs" of losing precious European achievements: high regulatory standards and the welfare state.

Hirschman $(1991,168-9)$ argues that when faced with a 'jeopardy thesis' supporters may appeal to two types of rhetoric: 'intransigence' or 'democracy friendly.' The latter is so-called because it entails deliberation and the modification of initially held opinions. 'Intransigence' includes two possible forms of rhetoric, 'mutual support' and 'dangers of inaction' (p.150-151). 'Mutual support' involves positive messages, putting forward reasons why T'TIP will not jeopardise what has been achieved. 'Dangers of inaction' implies negative messages, emphasising the harm that will come from inaction-i.e., a lack of TTIP (p.152). Hirschman considers both reactions intransigent because they present benefits and dangers as entirely certain and inescapable. Conversely, 'democracy friendly' rhetoric represents a more 'mature' approach where uncertainty is recognised and the risks of both action and inaction are 'canvassed, assessed, and guarded against to the extent possible' (p.153).

Building on Hirschman, Brink (2009) suggests that supporters have a third rhetorical option, a 'functional' approach. Here, supporters take note of the predominant opposing rhetoric and embed their argument within that discourse. They thereby protect their position from any attack that may stem from the three topoi of perversity, futility or jeopardy (Brink 2009, 117). Such a scenario does not involve supporters' willingness to change their negotiating position and therefore differs from a 'democracy friendly' strategy. A functional rhetoric approach would defend TTIP by using opponents' language and standpoints. Given that TTIP opponents have erected themselves as the protectors of European values (high standards) and democracy (public policies), a functional strategy would accept that values and democracy are at the forefront of EU trade policy, and link these goals to 'mutual support' and 'danger of inaction' scenarios.

To analyse the Commission's evolving rhetoric on TTIP, we have undertaken a qualitative content analysis of speeches made by Trade Commissioners on TTIP since the launching of the Transatlantic Business Council in December 2012. Qualitative content analysis is not a contradiction in terms; it is a research method that 'tries to synthesize openness - as claimed by the qualitative research paradigm - and theory-guided investigation - usually demanded by the hypothetical deductive paradigm' (Kohlbacher 2006, point 5.2.1). Contrary to discourse analysis, such a method identifies key discursive elements through a deductive rather than inductive procedure. Yet, it diverges from quantitative content analysis by adopting an interpretative focus on discourse changes and framings. In the words of Zhang and Wildemuth (2005, 1), 'qualitative content analysis goes beyond merely counting words or extracting objective content from texts to examine meanings, themes and patterns that may be manifest or latent in a particular text.'

We focus on the EU Trade Commissioner; they oversee all trade negotiations, and are the official representative and spokesperson on EU trade. Commissioner Karl De Gucht gave ten

\footnotetext{
${ }^{6}$ See for example AFL-CIO, 'U.S.-EU Free Trade Agreement (TTIP)', http://www.aflcio.org/Issues/Trade/U.S.-EUFree-Trade-Agreement-T'TIP, (accessed 2 January 2016) and German IG Metal 'Freihandelsabkommen sofort stoppen' http://www.fr-online.de/wirtschaft/freihandelsabkommen-eu-usa--freihandelsabkommen-sofort-stoppen,1472780,26460308.html (accessed 3 March 2016)
} 
speeches on TTIP in 2013 and eight in 2014, before stepping down; his successor Cecilia Malmström gave two speeches in November and December 2014, 20 in 2015 and 13 from January to July 2016. We analyse 27 speeches, including over 50\% of speeches in each year 2013-2015, and the first half of 2016. We do not discriminate between speeches on grounds of the audience because the objective is to establish whether the Commissioners' rhetoric strategy changed rather than whether the discourse catered to particular audiences. As summarised in table 1, the qualitative content analysis of these speeches distinguishes between positive ('mutual support'), negative ('dangers of inaction'), conciliatory ('democracy friendly'), and functional (adopting opponents' language but not their position) messages. As we show below, while the Commission has consistently been conciliatory regarding ISDS, its rhetoric on other issues of contention (economic and geopolitical benefits and EU standards) has become increasingly functional and intransigent.

Table 1. Commission's possible responses to opponents' jeopardy thesis

\begin{tabular}{|l|l|}
\hline \multicolumn{1}{|c|}{ Possible responses to opponents' jeopardy rhetoric } & \multicolumn{1}{c|}{ Meaning } \\
\hline Positive messaging & TTIP will improve the status quo \\
Negative messaging & The status quo is in danger without TTIP \\
Conciliatory messaging & TTIP costs should be considered \\
Functional messaging & $\begin{array}{l}\text { European values and democracy are more important } \\
\text { than material or geopolitical benefits }\end{array}$ \\
\hline
\end{tabular}

To make this article easier to follow, we divided the subsequent content analysis into two sections, one per Commissioner. De Gucht's term in office covered a shorter and less hotly contested period of the negotiations than did Malmström's (still in office as of April 2018), resulting in fewer speeches by De Gucht, and thus fewer speeches included in our analysis. However, while personalities matter, the Trade Commissioner represents the entire European Commission, so when showing the evolution of the rhetoric used by the Commissioner it is appropriate to include all the speeches addressing TTIP during the period in question. When citing or referencing a speech by either Commissioner we reference the date of the speech. We also organize our findings around the four key issues of contention: the economic and geopolitical benefits claimed by TTIP supporters and the lower standards and ISDS problems put forward by the opponents (Siles-Brügge, 2018). By doing so, we realised two things: First, functional messages are more difficult to identify than positive, negative or conciliatory ones. They tend to be general in character and actors can apply them to all possible issues of contention. Consequently, some of Malmström's functional messages are not allocated to any specific issue. Second, we added transparency as an issue of contention, since TTIP opponents frequently raised the demand for more transparency from negotiators. While such demands cannot be considered an argument solely against T'TIP, they were nevertheless relevant as they targeted the EU's trade policy procedures.

\section{The Commission's rhetoric under De Gucht}


Under Karel De Gucht, the number of arguments used to back TTIP were progressively enlarged, reflecting the gradually increasing complexity of the debate.

\section{Economic benefits}

The first argument put forward was that TTIP would bring economic benefits, and both positive and negative rhetoric was used to this effect in 2012. In a speech on 5 December 2012, De Gucht claimed that TTIP would provide economic growth, because any agreement between the US and the EU would create an economic multiplier effect (due to the size of the partners' commercial relationship), further integration (the high level of integration between the two partners' economies mean better integrated value chains), and improved confidence (companies could better plan for the future). De Gucht also argued that the costs of inaction would be high and that there was no stable and beneficial status quo as both partners (the US and EU) were simultaneously negotiating and signing other bilateral trade agreements. However, the negative messaging soon dissipated as the Commissioner concentrated on the positive reasons for TTIP. Moreover, in 2013, a large study quantified the economic benefits of TTIP (2 March 2013, referencing Francois, 2013) and the geographic reach expanded, with De Gucht stating TTIP's clear impact on third countries: 'The economic benefits of this agreement will not be confined to the transatlantic area. This is because much of what we plan to do will not discriminate against any of our other trading partners, developing or developed.' (21 May 2013, 4).

In 2014, the emphasis continued to be on positive messaging, adding specific examples, as well as a new insistence on how small and medium enterprises, who currently "find it much harder to get over barriers to trade" (22 May 2014, 3), would benefit from TTIP. Furthermore, as protests by civil society organisations intensified, TTIP was said to also 'give consumers better access to a wider range of high quality goods and services at better prices. That means they'll get more choice for their euro for products like cars.' (22 May 2014, 3).

\section{Geostrategic benefits}

Geostrategic issues were at first used by De Gucht to explain TTIP's positive consequences for the wider multilateral trading system. 'An EU-US partnership can act as a policy laboratory for the new trade rules we need ...' because 'its [WTO] negotiating agenda is blocked, largely because of differences of view between developed powers like the US and the rising stars.' (2 March 2013, 3-4.) Thus, 'through these negotiations we will in fact seek to strengthen the World Trade Organisation and the multilateral trading system it oversees.' (19 April 2013, 2). A few months later, by October 2013, De Gucht began to emphasise TTIP's geostrategic importance to counteract fears regarding standards, "TTIP can support international cooperation on regulatory issues ... we should seek to exercise joint leadership on these issues. If we do not, others will.' (negative message) (10 October 2013, 6-7). From then on, speeches began highlighting the idea that TTIP would allow the EU to preserve its ability to set global standards and by do doing improve upon the status quo (positive message). At his 22 May 2014 speech in Berlin, tellingly titled "EU Trade Policy as a Means to Influence Globalization," De Gucht explained that 'If we want to continue to shape the norms, rules, standards and disciplines that are so important in a globalized economy, we have to realise that 
we cannot do this without partners.' (22 May 2014, 4). He later added that 'TTIP is about securing our values in a changing world.' (3 July 2014, 4). In April 2014, De Gucht added an additional issue framed as a positive message, this being TTIP's ability to address 'the geopolitical challenge posed by Europe's dependence on Russian gas exports.' (10 April 2014, 3). De Gucht further emphasised the security dimension of TTIP in a speech in Warsaw two months later (6 June 2014, 3).

\section{Lower standards}

De Gucht also used positive messaging to negate opponents' claims regarding the lowering of EU standards. ${ }^{7}$ In 2013, De Gucht explained how regulatory convergence would not lead to a race to the bottom, but instead set higher standards. On 10 October 2013, De Gucht argued that the Single European Market is 'the world's most advanced, most revolutionary, experiment in regulatory cooperation.' (10 October 2013, 3) and it shows that 'There doesn't need to be a trade-off between high standards and open markets.' (10 October 2013, 4) He also explained how 'nothing we will agree [on] under this agreement will lower standards of protection.' (10 October 2013, 6) He argued that TTIP, just as the Single Market, will be based on 'principles of openness and transparency.' (10 October 2013, 4). By 2014 the rhetoric became less pedagogic and more pragmatic (even conciliatory), highlighting how the EU would prevent any lowering of standards thanks to the inclusion of 'clear statements that both sides retain the right to regulate.' (10 April 2014, 3). Nevertheless, in Berlin, on 3 July 2014, De Gucht accused the President of the Academy of the Arts, Klaus Staeck, of fearmongering (he had said on German Television that he did not trust the Commission staff), asking the public 'Why frighten people when the facts speak for themselves?' (3 July 2014, 4). He also described declarations that education would suffer because of TTIP as 'absurd' (3 July 2014, 4). ${ }^{8}$

\section{Investor-to-State Dispute Settlement}

The issue of ISDS only began appearing in De Gucht's speeches in early 2014, alongside demands of transparency and openness. Opponents linked transparency to ISDS because ISDS is based on secret arbitration, but transparency was also linked to all other areas of the negotiations (see GarciaDuran and Eliasson, 2017; Gheyle and De Ville, 2017). De Gucht approached it in a conciliatory fashion after several CSOs had organised protests and petitions in 2013 and 2014 (see Siles-Brügge, 2018). In April 2014, De Gucht explicitly referred to the ISDS debate raging in the EU and the Commission's recently launched public consultation, with the goal 'to create a new, improved type of investment agreement.' (10 April 2014, 4). In May 2014, while clearly supporting the need for investment protection in TTIP, the Commissioner declared 'that there is room for debate, interpretation or improvement...' (10 April 2014, 2) while emphasising that 'it is our chance to set a model for future agreements all around the world.' (10 April 2014, 3).

\section{Transparency}

\footnotetext{
${ }^{7}$ On the latter see for example DeVille and Siles-Brügges 2016.

${ }^{8}$ De Gucht specifically referred to declarations by Mr. Beckmann from the German teacher's association on how 'German teachers could be replaced by American Apps' with TTIP (3 July 204, 4).
} 
On 6 June 2014, De Gucht expressed surprise at accusations that TTIP negotiations were undemocratic and opaque, pointing out that the European Commission publishes its negotiation positions, consults with stakeholders, and seeks counsel of the European Parliament, all with the strong support of the EU governments in the Council,' and that 'no deal can pass without the approval of both these bodies.' (6 June 2014, 2).

Before leaving office, De Gucht used conciliatory rhetoric, emphasising all the ways in which the European Commission had become more transparent by engaging with constituents on trade.

We have an open door policy to anyone who is interested in the negotiations - whether from business, NGOs trade unions or consumer organisations. We also have structured dialogues with these different groups. ....we have organised, jointly with the US, dedicated, day-long stakeholder consultation sessions during each negotiating round ... a standing advisory group of experts, carefully balanced to represent a broad range of interests including labour rights, the environment, health, consumer rights and business. (7 October 2014, 4)

\section{The Commission's rhetoric under Malmström}

Under Cecilia Malmström the DG Trade communication assumed an increasingly functional approach. We consider it functional rather than conciliatory for two reasons. First, because TTIP is now framed by the Commission as serving civil society (using the language and standpoints of opponents). Second, Malmström's defence of TTIP nevertheless reinforced De Gucht's positive messaging and added negative messaging on the issues of contention. As shown below, while the Commission was prepared to accept TTIP as special, and indicated that changes to ISDS and transparency were necessary, it was also adamant in defending TTIP's benefits, rejecting opponents' arguments regarding the lowering of standards and the need to exclude investor protection.

De Gucht's successor made civil society demands, specifically consumers' needs, a main priority. Two weeks after becoming Trade Commissioner, Malmström stated at a conference at the European Parliament that 'the only valid measure of the success of this negotiation will be whether it improves people's lives' (18 November 2014, 1). TTIP can do so by addressing 'the full range of consumers' needs,' she added (18 November 2014, 3); that is, by promoting growth and jobs as well as better government and a stronger voice in the world. One month later, she recognised there was a need for 'all sides [to] engage in real, honest debate ...' and made a concession: 'So let me start by accepting one important point often made against TTIP. This is not just another trade negotiation. And we should not present it to people that way' (11 December 2014, 1). She also presented herself and the Commission at the service of the people:

I am listening ... this agreement needs to be negotiated openly and transparently ... we will open up the ways documents are shared with the European Parliament to make it easier for them to hold us to account ... we negotiate in the interest of our people and we negotiate openly and honestly. (11 December 2014, 1-3)

Trade for All, the Commission's 2015 trade policy strategy, represents the pinnacle of her functional efforts

we have learned from the TTIP debate. On the one hand, we have learned that people do want more trade. They see how it can benefit our society. But on the other hand, we have learned that they don't want to compromise on the core principles of European society in order to get those benefits. ...they have helped shape our approach [and] our new overall EU trade strategy. ... In our new approach, trade is not just about our economic interests but also about our values (19 October 2015, 5-6). 
A subtle change in discourse accompanied the release of Trade for All. While the Commission's communication continued aiming at making consumers, and civil society in general, feel included, ${ }^{9}$ the Commission began signalling that trade policy had already adapted to Europeans' demands. By 19 October 2015, Malmström stated that in the Commission's new trade strategy 'We have taken a clear pledge: No trade agreements will ever lower levels of consumer, environmental or social and labour protection; Any change to levels of protection can only be upward; And we will never give up our right to make policy in the public interest.'(19 October 2015, 6). On 25 April 2016, she added that 'trade agreements need to be about more than economics ...' (25 April 2016, 4), not only because of the TTIP debate, but also 'because it is written in the EU's Lisbon Treaty. The European Union's trade policy is part and parcel of its wider foreign policy and must support broader objectives.' (25 April 2016, 5).

\section{Economic and geostrategic benefits}

While De Gucht distinguished between the economic and geostrategic benefits of TTIP, Malmström saw them as linked; she also increasingly emphasized sovereignty and competitiveness in order to present TTIP as a positive development. On 30 January 2015, she tied geostrategic benefits to the sovereignty question: '[TTIP] is not about surrendering sovereignty but about strengthening Europe's position in the world at a time of great change.' (30 January 2015, 2) In Riga, on 1 June, they were linked to global value chains and therefore to economic benefits, 'TTIP will benefit Europeans by giving us a stronger voice in the world ... at a time when the world is becoming more important in our lives [because] the world economy is becoming more integrated.' (1 June 2015, 3) This positive framing complemented new negative messaging: geostrategic benefits (and indirectly economic benefits) depended on the correct 'timing', and maintaining the status quo was impossible (1 June 2015; 3 June 2015; 11 June 2015). On 22 June 2015, Malmström stressed how it was

vital that we seize this opportunity now. The fact is that the size of the US and EU economies relative to the rest of the world is shrinking. ... We need to be ready to try new things .... As Tancredi Falconieri says in ... 'Il Gatopard': 'If we want things to stay as they are, things will have to change.' (22 June 2015, 6).

In September 2015, the Commission also stressed that T'TIP was not a substitute for, but rather a complement to multilateralism. In doing so, it rejuvenated an argument first made by De Gucht in 2013, but since excluded from the Commission's rhetoric. Using multilateralism as a source of positive messaging, Malström stated, 'we need to keep multilateralism in mind when we negotiate our bilateral and regional free trade agreements ... through the bilateral we are preparing the ground for future multilateral work.' (25 September 2015, 2). Her post-Nairobi speech in January 2016 optimistically affirmed 'that WTO is alive and able to make decisions.' (25 January 2016, 1). On 25 February 2016, Malmström linked economic benefits with efforts both at the multilateral and bilateral level (25 February 2016, 5), explaining that one of the arenas of mutual US and EU support is the W'TO, revitalised after Bali and Nairobi (10 March 2016, 2). Three months later, she insisted that 'bilateral and regional deals like TTIP can support the multilateral system by acting as policy laboratories of sorts.' (2 May 2016, 3).

The Commission also consistently stressed that TTIP is (a key) strategic part of a broader EU bilateral trade policy, a strategy to re-energise the European economy. That strategy involves

\footnotetext{
92016 started with speeches with rather telling titles: “TTIP: What consumers have to gain" (26 January 2016) and "TTIP and EU Trade: Listening, learning and changing" (22 February 2016)
} 
'working for progress at the WTO. It also involves a comprehensive set of negotiations for bilateral free trade agreements on all continents.' (1 June 2015, 2). On 7 July 2015 Malmström clarified that 'TTIP is an essential part of the Commission's strategy to open markets around the world' (7 July 2015, 1). Later she explained that,

TTIP is in fact just a part - the biggest part but a part nonetheless - of our wider efforts on trade. We are using a full range of trade policy tools to boost our economy and help us adapt to a changing world. We are working on more than 20 agreements with more than 60 countries across the Americas, Asia and Africa. (25 September $2015,1)$

Following publication of the Trade for All strategy in October 2015, Malmström linked TTIP directly to the EU's global trade strategy. On 17 November 2015 she argued that TTIP was 'only one part of our broader strategy. ... our goal is not just to make it easier to connect to the US, which is our closest partner, but to make Europe a platform for engaging the whole word' (17 November 2015, 3). On 25 February 2016, she defended that 'we need an active and ambitious international trade policy ...' because 'the question is not "Do you trade with Asia, Europe or America?" but, "Are you integrated in these value chains or aren't you?" ... countries are queuing up to negotiate with us.' (25 February 2016, 3-5). On 15 March 2016, Malmström explained how 'the TTIP negotiations only make sense in this broader context. The aim is an EU economy that is open for business with the world, not just with the US ... TTIP is part of the solution but it's also part of the wider picture too.' (15 March 2016, 4 and 7). This wider picture is where 'the objectives of the EU's trade policy are clear-create economic opportunity and protect and project our values.' (15 March 2016, 7).

\section{Lower standards}

Upon entering office, Malmström began explaining with more precision what regulatory convergence would imply. On 18 November 2014 she stated that the Commission has to 'focus our work on those areas where EU and US regulations follow similar standards.... we must not change our laws in areas where they are just too different ... we must not restrict our ability to regulate on future issues when we need to' (18 November 2014, 2-3). That explanation became habitual in her speeches. On 19 March 2015, Malmström offered another reason not to be afraid of regulatory convergence- the EU's experience in this area through not only the European Single Market and the World Trade Organization (WTO), but also through bilateral agreements (for example with South Korea or Canada). On 27 March she proudly reminded the public that 'Last week Ambassador Froman, my US counterpart, and I released a joint statement making exactly these points [nothing in TTIP will affect how national governments choose to deliver public services].' (27 March 2015, 4)

Despite this conciliatory approach, the Commission also proved resourceful in adding new positive messages to counteract opponents' arguments. In February 2015, for example, Malmström explained there are several reasons TTIP can help deliver 'more effective government.' (5 February 20015, 2). She said,

the EU and the US have some of the most qualified regulatory experts in the world ... when regulators cooperate they make better regulation ... when authorities cooperate they can enforce the rules better. ... [and] governments would be able to buy cheaper goods and services "saving taxpayers money" ... [and] that means more money in the public purse to pay for public services like health and education and strong enforcement of regulations. (5 February 2015, 2) 
On 19 October 2015, Malmström's positive framing became more aggressive. Besides insisting that 'in most areas American and European regulations are very similar ...' and that 'without a doubt we have much more in common with the US than we do with many other partners', she noted for the first time that 'in some cases US rules are even stronger.' (19 October 2015, 4). On 12 January 2016, she was more direct, saying that 'in some cases US rules are even stronger than ours. That's what last year's revelations about Volkswagen showed us.' (12 January 2016, 3). In the other cases (where US rules or standards are lower), TTIP can help ensure higher standards, Malmström added. On 25 April 2016, she claimed 'The EU also hopes TTIP can help increase the uptake in the US of international standards ... encourage US standards development organisations and users of standards to view [ISO and IEC standards] more positively.' (25 April 2016, 4).

\section{Investor-to-State Dispute Settlement}

In January 2015, Malmström recognised that existing language in treaties with ISDS favoured investors, thus

the traditional approach to investment protection agreements is too narrow. When people were drafting these agreements they were more focused on protecting investment than they were on making sure that governments could regulate in the public interest. That imbalance between investor rights and government led to some of the cases that shocked people so much. I don't want an ISDS like that. (30 January 2015, 5).

In February, she added 'If people are taking the time to listen and learn then we owe them the truth, not a new batch of euromyths.'(16 February 2015, 5). On 22 April she acknowledged that 'the Commission also believes that the existing investment agreements are old fashioned and need to be updated.' (22 April 2015, 3) and that TTIP involved risks, 'there are benefits to be had from freeing up trade with the United States. And second that there are risks to be avoided as we do that.' (22 April 2015, 1). Nevertheless, the Commission framed the need to include investor protection and dispute settlement in TTIP predominantly through intransigent rhetoric, in this case predominantly positive messaging. After recognising that CSOs had legitimate worries about the issue (in a speech on 30 January 2015), she progressively built an argument based on the idea that TTIP constituted an opportunity to modernise investment protection because international investment policy had become EU competency. She summarised the argument in a speech to the International Trade Committee of the European Parliament on 18 March 2015 that focused on this topic,

\footnotetext{
the Commission shares most of the concerns that have been raised. Since we got the competence for investment our view has been clear: the current network of agreements in place is not fit-for-purpose in the $21^{\text {st }}$ century .... And that is why we started to reform ISDS already in the Canadian agreement, CETA. ... the question about putting investment in T'TIP is not whether we should do it but how we can do it right ... we should aim for a court that goes beyond TTIP. (18 March 2015,1-3).
}

On 22 June 2015, she presented TTIP as a way to move towards an international investment court system (ICS); a way to create 'a model for the rest of the world to follow.' (22 June 2015, 5). In response to CSO criticism that ICS was little changed vis-à-vis ISDS. On 17 November 2015, she emphasised how the EU's proposal on ICS in TTIP 'opens the way toward our medium term goal: an international investment court.' (17 November 2015, 3). Despite continued civil society opposition ('ICS was ISDS by another name') and increased public scepticism among Member State governments (especially France and Germany) the Commission persisted, attempting to strike a balance between government's rights to regulate and investor protection. In January 2016, 
Malmström asserted that 'we have decided to take the lead on the global effort to reform and modernize the overall [investment protection] system.' (12 January 2016, 4). Negative rhetoric is found in just one speech. On 22 April 2015, she stated that some form of arbitration was necessary in TTIP to 'make sure that European companies don't find themselves at a disadvantage in the US when Japanese and Canadian companies have their investments protected.' (22 April 2015, 3).

\section{Transparency}

By June 2015, Malmström had begun enumerating the efforts she was making to listen and respond to people's concerns. On 1 June 2015, she explained practical steps. 'We're meeting with anyone who has an interest in these talks to explain them-consumer groups, trade unions, environmental organizations and other interested parties .... And I am personally talking to as many parliaments as possible.' (1 June 2015,4$)$. On the $22^{\text {nd }}$ of that month, she declared that 'I have worked to put transparency and discussion about all issues and citizens' concerns at the centre of trade policy ... we are engaging with civil society groups, campaigners and the wider public more than ever.' (22 June 2015, 5). In July, she added that 'I hope that all these people [national parliaments, NGOs, civil society and other stakeholders] see the changes that we have made to take account of their views.' (7 July 2015,2). The changes she was referring to included opening the negotiations to 'unprecedented public scrutiny' (7 July 2015, 2), which 'made clear where we stand on public services [and] on regulation' (7 July 2015, 2-3); the EU also 'made proposals for a deep reform of investment protection.' (7 July 2015, 3). In October, Malmström stressed the efforts of the Commission to continuously communicate with civil society, asking rhetorically 'Did you know that during each round our negotiators stop for a day to hear presentations and then take questions from hundreds of civil society organizations?' (16 October 2016,3). She went on to emphasise how transparency is a principle of Trade for All, stating,

The EU needs to make sure that people trust in what we are doing on their behalf. The best way to do that is to let them see for themselves. So, we are going to approach all our agreements as we do TTIP -releasing many more documents and engaging more closely with the European Parliament and national parliaments. (19 October 2015, 6).

\section{Interpreting the results}

Our qualitative content analysis reveals (as summarised in table 2) consistency in the arguments of both Commissioners, with Malmström's messaging largely building on that of her predecessor (as one might expect). Though Malmström's tenure covered a longer period of TTIP negotiations, both were conciliatory regarding ISDS and transparency, but intransigent (through both positive and negative messaging) regarding the economic and geostrategic benefits of TTIP and its impact on EU standards. Nevertheless, the analysis also reveals a change: under Malmström the rhetoric became more functional than under Karel De Gucht. In other words, while the substance of the messages was consistent during the whole period (although they became more elaborate), the style of delivery changed. ${ }^{10}$

\footnotetext{
10 While the personalities of the Commissioners (De Gucht was widely seen as brash, Malmström as more conciliatory) may have impacted the style and content of the Commission's rhetoric, the focus here is on how, and to what extent, rhetoric changed.
} 
Table 2. De Gucht and Malmström rhetoric on TTIP (December 2012 - July 2016)

\begin{tabular}{|c|c|c|}
\hline Issues & $\begin{array}{l}\text { De Gucht } \\
\text { ARGUES }\end{array}$ & $\begin{array}{l}\text { Malmström } \\
\text { ADDS }\end{array}$ \\
\hline $\begin{array}{l}\text { Economic } \\
\text { benefits }\end{array}$ & $\begin{array}{l}\text { POSITIVE } \\
\text {-Quantification } \\
\text {-Examples (SME) }\end{array}$ & $\begin{array}{l}\text { POSITIVE } \\
\text {-Global Value Chains } \\
\text {-Part of broader trade strategy } \\
\text { NEGATIVE } \\
\text {-Timing } \\
\text {-Status quo not possible } \\
\text { FUNCTIONAL } \\
\text { Way to ensure what citizens want: jobs }\end{array}$ \\
\hline $\begin{array}{l}\text { Geostrategic } \\
\text { benefits }\end{array}$ & $\begin{array}{l}\text { POSITIVE } \\
\text {-Preserve European standards and values } \\
\text {-Less dependence on Russia energy }\end{array}$ & $\begin{array}{l}\text { POSITIVE } \\
\text {-Stronger voice } \\
\text {-Multilateralism } \\
\text { NEGATIVE } \\
\text {-Timing } \\
\text {-Status quo not possible } \\
\text { FUNCTIONAL } \\
\text {-Way to ensure what citizens want: preserve } \\
\text { European standards and values }\end{array}$ \\
\hline $\begin{array}{l}\text { Lower } \\
\text { standards }\end{array}$ & $\begin{array}{l}\text { POSITIVE } \\
\text {-Single European Market } \\
\text { CONCILIATORY } \\
\text {-Inclusion of right to regulate }\end{array}$ & $\begin{array}{l}\text { POSITIVE } \\
\text {-Stronger regulation and better public services } \\
\text {-Some US rules stronger } \\
\text {-US rules may become stronger } \\
\text { FUNCTIONAL } \\
\text {-Society demands in general and consumers' } \\
\text { needs focus } \\
\text {-Trade for All pledge not to lower standards or } \\
\text { give up right to decide public policy } \\
\text { CONCILIATORY } \\
\text { Joint statement with US Ambassador }\end{array}$ \\
\hline ISDS & $\begin{array}{l}\text { CONCILIATORY } \\
\text {-Room for debate } \\
\text {-Public consultation }\end{array}$ & $\begin{array}{l}\text { POSITIVE } \\
\text {-Opportunity to solve EU BITs problems } \\
\text {-Model for the rest of the world } \\
\text { FUNCTIONAL } \\
\text {-Society demands in general and consumers' } \\
\text { needs focus } \\
\text {-Trade for All pledge } \\
\text { CONCILIATORY } \\
\text {-Need to improve ISDS }\end{array}$ \\
\hline
\end{tabular}




\begin{tabular}{|l|l|l|}
\hline & $\begin{array}{l}\text { CONCILIATORY } \\
\text {-Publication mandate and some negotiating } \\
\text { Transparency }\end{array}$ & $\begin{array}{l}\text { CONCILIATORY } \\
\text {-Society demands in general and consumers' } \\
\text {-Structural dialogues with CSOs } \\
\text { dialogue }\end{array}$ \\
& \begin{tabular}{l}
-Trade for All principle \\
\hline
\end{tabular} \\
\hline
\end{tabular}

Source: Authors' elaboration.

Following Brink (2009), these results indicate that the Commission learned to present its arguments using opponents' language and standpoints. As discussed, Malmström claimed that TTIP was a means of preserving EU values and democracy. Through TTIP, the EU would be able to export its values and norms and establish a better equilibrium between the rights of foreign investors and democracy. While the DG Trade continued to consider T'TIP a good option, due to its economic and geopolitical benefits, the message became that those benefits served European values and democracy. At the same time, our analysis shows that, in Hirschman's terms, the Commission's discourse became more intransigent over time. Under Malmström the Commission added negative messaging to defend the deal's economic and geostrategic benefits, and positive messaging to counter opponents' claims regarding both lower standards and ISDS. While opening the ISDS system to public discussion and consultation, and then reforming the policy, the Commission remained adamant on its inclusion in the agreement through its new format, the ICS, where governments' rights to regulate in the public interest would be greatly enhanced and strict limits placed on investors' rights to sue governments over public policy. However, the Commission altered the process of engaging the public and promoting trade (more transparency, dialogue, and structured meetings). In short, the response to TTIP contestation from 2013 to 2016 was more functional (process oriented) than conciliatory (giving in on policy).

The question of whether functional theses are more important than conciliatory ones in terms of their impact on EU trade policy remains unclear. However, in conciliatory cases the Commission professes to make or have made concessions to opponents. Since, in the case of TTIP, these concessions largely refer to ISDS and transparency, we affirm that this rhetoric reflects an impact on EU trade policy. The Commission changed the process of EU trade policy promotion (more transparency, dialogue, and structured meetings) and proposed a new investor-state dispute settlement system to serve as a template for all its free trade agreements.

In principle, one would not expect functional rhetoric to lead to any changes in EU trade policy. Using the language and standpoints of opponents does not equal a concession. Instead, conciliatory (or democracy friendly) rhetoric may be used in maintaining key arguments. Yet, as this analysis has shown, a functional rhetorical strategy may have unintended consequences. ${ }^{11}$ The rhetorical theses of the Commission towards European values and democracy were inserted in Trade for All, thereby becoming an integral part of the Commission's trade strategy. By so doing, the Commission put EU values on the same level as economic interests. Whether such rhetorical commitment forces the Commission to be more open to other, future CSO demands emanating from concerns with other negotiations remains unclear. While the Commission's 2017 report on trade and globalisation reiterated the importance of European values, proposing to increase transparency and the inclusiveness of trade policy-making (Commission 2017), CSOs admit being worried about trade's salience in the public eye post-TTIP, or even a long-term pause, and no activism or public outcry surrounded the EU-Vietnam or EU-Japan negotiations (Eliasson and

\footnotetext{
${ }^{11}$ Schimmelfenning (2001) and Grube (2016) point out that changes in rhetoric may have lasting effects ('rhetorical entrapment' and 'rhetorical path dependency' respectively).
} 
Garcia-Duran, 2018). ${ }^{12}$ Does that mean that in the future opponents will not exploit the rhetorical commitment of the Commission? These questions will only be assessable at a later stage and are part of the larger debate on whether TTIP represents an anomaly in public engagement on trade and TTIP's lasting consequences (Gheyle and De Ville 2017; De Bièvre and Poletti 2017). In any case, the answers to such research will clarify the extent to which adopting the language and standpoints of opponents, and bringing EU values to the forefront of the EU's trade policy strategy, set trade policy on a path to more change.

This article demonstrates that looking at supporters' responses to contested trade negotiations where opponents have been able to mobilise public opinion sheds light on the impact of such politicisation. Assessing the evolution of the Commission's rhetoric in the TTIP case shows how the Commission changed the way it addressed the opposition (more accommodating), altered the process of engagement with the public and the promotion of trade (more transparency, dialogue, and structured meetings), and illustrates how the opposition affected trade policy (reflected in process changes and changes to ISDS). Since this article shows that changes in the Commission's rhetorical strategy and EU trade policy occurred, we believe it warrants further research on how the changes affected public opinion. Public opinion on TTIP stabilised in late 2016, just as negotiations froze. There was a slight uptick in support for TTIP in a few countries (for example Sweden, the Czech Republic and the United Kingdom). Specifically, support rose among respondents who said they had learned about TTIP, opposition plateaued in countries where CSOs initially made inroads, including Germany, France and Italy (Eurobarometer 2016; Dalia 2016).

\section{Disclosure statement}

No potential conflict of interest was reported by the authors.

\section{Notes on contributors}

Patricia Garcia-Duran Huet is associate professor at the University of Barcelona, and a member of the Observatory of European Foreign Policy, Institut Barcelona d'Estudis Internacionals (IBEI). Email: patriciagarciaduran@ub.edu

Leif Johan Eliasson is professor at East Stroudsburg University, Pennsylvania. He has published two books, including America's Perceptions of Europe (2010, Palgrave MacMillan), and numerous articles on trade, European integration, and transatlantic relations in prominent academic journals. Email: jeliasson@esu.edu

\section{Acknowledgments}

This article has been presented at different stages of completion in three conferences: UACES September 2016 (London), EUSA May 2017 (Miami), and EISA September 2017 (Barcelona). The authors would like to thank the participants for their constructive and useful feedback, but in

\footnotetext{
12 'we cannot get our members interested' one CSO representative, interview Brussels, May, 2016. In 2017 we inquired with the European Parliament, and the International Trade Committee had received only a handful of inquires about the EU-Japan negotiations in 2015 and 2016. Email correspondence available from authors.
} 
particular the discussants of the panels as well as Matthias Goetz, Maria Garcia, Robert Ackrill, and Miguel Otero. We are also grateful to Alasdair Young and participants in a 2016 workshop in Atlanta for comments on earlier drafts, and four anonymous reviewers for useful feedback on our initial submission. Research for this article was supported by the National R+D Plan of the Spanish Ministry of Economy and Competiveness (CSO2016-79205-P).

\section{References}

Aline, Robert (2015) 'European Parliament backs TTIP, rejects ISDS'. EurActiv July 13, https://www.euractiv.com/section/global-europe/news/european-parliament-backs-ttip-rejectsisds/ accessed 3 July, 2016

Bauer, Matthias (2016) 'Manufacturing discontent - the rise to power of anti-TTIP groups'.

November 28, European Centre for International Political Economy, http://ecipe.org/publications/manufacturing-discontent-the-rise-to-power-of-anti-ttip-groups/ accessed 4 March, 2017

Borderlex (2016) 'Brussels briefing on trade', $<$ http://www.borderlex.eu/eutradeinsights/malmstrom-ttip-to-remain-in-a-freezer-for-quite-sometime $>$, accessed 1 January 2017

Brink, Alexander (2009) 'Hirschman's rhetoric of reaction: US and German insights in business ethics', Journal of Business Ethics, 89, 109-122

Ciofu, Sabina Maria and Stefanuta, Nicolae (2016) 'TTIP, the bullied kid of Twitter', Georgetown Public Policy Review, http://gppreview.com/2016/01/14/ttip-twitter-and-how-social-media-is-defining-thepublic-argument, accessed 1 March 2017

Dalia Research (2016) 'eu28 survey data', <https://daliaresearch.com/e28>, accessed 1 September 2017

De Ville, Ferdi and Siles- Brügges, Gabriel (2016) TTIP: The Truth About the Transatlantic Trade and Investment Partnership (London: Polity)

De Wilde, Pieter (2011) No polity for old politics? A framework for analysing the politicization of European integration' Journal of European Integration, 33:5, 559-575

Dempsey, Judy (2015) 'Come on Europe, Go for TTIP!', Carnegie Europe, 12 October, http://carnegieeurope.eu/strategiceurope/61584 accessed 14 October, 2015..

Eliasson, Leif Johan and Patricia Garcia-Duran (2018) 'T'TIP negotiations: interest groups, antiTTIP civil society campaigns and public opinion' Journal of Transatlantic Studies, https://doi.org/10.1080/14794012.2018.1450069

EU Trade Commission, speeches on TTIP, Multiple, 1 December 2012 - 30 July 2016, $<\underline{\text { http: } / / \text { trade.ec.europa.eu/doclib/cfm/doclib results.cfm?key }=\mathrm{de} \% 20 \text { gucht } \% 2 \mathrm{C} \% 20 \mathrm{Malmstr} \% \mathrm{C}}$ $3 \% \mathrm{~B} 6 \mathrm{~m} \& \mathrm{ppt}=1 \& \mathrm{dis}=50 \& \mathrm{lan}=$ all $\& \mathrm{ty}=$ Speeches $\% 20 \mathrm{and} \% 20$ articles\&sta $=1 \&$ en $=50 \&$ page $=1 \& y e a r$ $1=01 / 01 / 2013 \& y e a r 2=30 / 07 / 2016 \&$ sector $=$ all\&country=all\&langId=EN $>$, accessed $21-25$ March 2017

European Commission (2017) 'Report from the Commission to the European Parliament, The Council, the European Economic and Social Committee and the Committee of the Regions on the Implementation of the Trade Policy Strategy Trade for All delivering a progressive trade policy to harness globalisation, http://trade.ec.europa.eu/doclib/docs/2017/september/tradoc 156037.pdf, accessed 14 September 2017

Eurobarometer 85 (2016) Standard Eurobarometer,

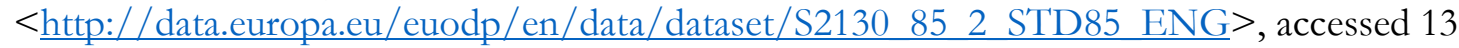
November 2016 
Finlayson, Alan (2013) 'Critique and political argumentation', Political Studies Review 11:3, 313-320 Finlayson, Alan (2007) 'From beliefs to arguments: interpretative methodology and rhetorical political analysis', British Journal of International Relations 9:4, 545-563

Francois, Joseph et al (2013) 'Reducing Transatlantic Barriers to Trade and Investment - An Economic Assessment. Final Report for the European Commission', Contract TRADE10/A2/A16, Center for Economic Policy Research, London

Friends of the Earth Europe (2015) 'How TTIP undermines food safety and animal welfare', 3

February, <http://www.foeeurope.org/how-T'TIP-undermines-food-safety-animal-welfare-

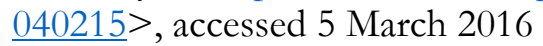

Garcia-Duran, Patricia and Eliasson, Leif Johan (2017) 'The public debate over Transatlantic Trade and Investment Partnership and its underlying assumptions', Journal of World Trade 51:1, 23-42

Gheyle, Niels (2016) 'Adding fuel to the flames. How TTIP reinvigorated the politicization of trade.

Conference article. Prepared for the GIFTA workshop series, social and labour impacts of free trade agreements, Brussels, Belgium, 7-8 July

Gheyle, Niels and De Ville, Ferdi (2017) 'How Much Is Enough? Explaining the continuous transparency conflict in TTIP' Politics and Governance 5:3,16-28

Grube, Dennis (2016) 'Sticky words? Towards a theory of rhetorical path dependency', Australian Journal of Political Science 51:3, 530-545

Hamilton, Daniel (ed) (2014). The geopolitics of TTIP; repositioning the Transatlantic relationship for a changing world, Centre for Transatlantic Relations, John Hopkins University

Hirschman, Albert (1991) The rhetoric of reaction: perversity, futility, jeopardy (The Belknap Press of Harvard University Press, Cambridg, MA)

Kohlbacher, Florian (2006) 'The use of qualitative content analysis in case study research', Forum: Qualitative Social Research, Vol. 7:1, Art. 21, < http://www.qualitativeresearch.net/index.php/fqs/article/view/75/154>, accessed 16 March 2017

Lamy, Pascal (2015) 'The new global trade agenda', Peterson Institute for International Economics (Washington DC, unedited event transcript)

Poletti, Arlo, and De Bièvre, Dirk (2013) 'The political science of European trade policy: a literature review with a research outlook' Comparative European Politics 12:1, 101-119.

Siles-Brügge, Gabriel (2018) 'Transatlantic Investor Protection as a Threat to Democracy: The

Potency and Limits of an Emotive Frame', Canbridge Review of International Affairs, 31:2, ??-??

Schimmelfennig, Frank (2001) 'The community trap: liberal norms, rhetorical action, and the eastern enlargement of the European Union', International Organization 55:1, 47-80

Shorten, Richard (2015) 'Reactionary rhetoric reconsidered', Journal of Political Ideologies 20:2, 179-200

Young, Alasdair (2016) 'Not your parents' trade politics: The Transatlantic Trade and Investment Partnership negotiations', Review of International Political Economy 23:3, 345-378.

Zhang, Yam and Wildemuth, Barcbara (2005) 'Qualitative analysis of content', Analysis 1:2, 1-12 